\title{
National prevalence survey in Brazil to evaluate the quality of microbiology laboratories: the importance of defining priorities to allocate limited resources
}

\author{
Luciano B. Costa, ${ }^{1}$ Maria Regina Alves Cardoso, ${ }^{2}$ Consuelo G. Ferreira, ${ }^{2}$ \\ Carlos E. Levy, ${ }^{3}$ Heder M. Borba, ${ }^{4}$ Janaina Sallas, ${ }^{4}$ Heiko T. Santana, ${ }^{4}$ \\ Rogério S. Lima, ${ }^{5}$ Lucia R. Ferraz, ${ }^{6}$ Joana D'Arc P. Reis, ${ }^{6}$ \\ Leandro Q. Santi, ${ }^{7}$ and Anna S. Levin ${ }^{1}$
}

ABSTRACT This report describes a survey of microbiology laboratories $(\mathrm{n}=467)$ serving Brazilian hospitals with $\geq 10$ intensive care beds and/or involved in the government health care adverse event reporting system. Coordinators were interviewed and laboratories classified as follows: Level 0 (no minimal functioning conditions-85.4\% of laboratories); Level 1 (minimal functioning conditions but inadequate execution of basic routine-6.7\%); Level 2 (minimal functioning conditions and adequate execution of basic routine but no adequate procedures for quality control-5.8\%); Level 3 (minimal functioning conditions, adequate execution of basic routine, and adequate procedures for quality control, but no direct communication with the infection control department-0.9\%); Level 4 (minimal functioning conditions, adequate execution of basic routine, adequate procedures for quality control, and direct communication with infection control, but no available advanced resources-none); and Level 5 (minimal functioning conditions, adequate execution of basic routine, adequate procedures for quality control, direct communication with infection control, and available advanced resources-0.9\%). Twelve laboratories did not perform Ziehl-Neelsen staining; 271 did not have safety cabinets; and $>30 \%$ without safety cabinets had automated systems. Low quality was associated with serving hospitals not participating in government adverse-event program; private hospitals; nonteaching hospitals; and those outside state capitals. Results may reflect what occurs in many other countries where defining priorities is important due to limited resources.

Key words Laboratories, hospital; health care surveys; quality assurance, health care; microbiological techniques; quality indicators, health care; Brazil.

\footnotetext{
Departamento de Moléstias Infecciosas e Parasitárias and Laboratório de Investigação Médica-LIM 54, Hospital das Clínicas, Faculdade de Medicina, Universidade de São Paulo, São Paulo, SP, Brazil. Send correspondence to: Anna S. Levin, gcih. adm@hc.fm.usp.br

2 Departamento de Epidemiologia, Faculdade de Saúde Pública, Universidade de São Paulo, São Paulo, SP, Brazil.
}

3 Departamento de Patologia Clínica, Faculdade de Saúde Pública, Universidade Estadual de Campinas, Campinas, SP, Brazil

4 Gerência Geral de Tecnologia em Serviços de Saúde, Unidade de Investigação e Prevenção das Infecções e dos Eventos Adversos, Agência Nacional de Vigilância Sanitária, Brasília, DF, Brazil.

5 Pan American Health Organization/World Health Organization, Brasília, DF, Brazil.
Coordenação Geral de Laboratórios de Saúde Pública, Departamento de Vigilância Epidemiológica, Secretaria de Vigilância em Saúde, Ministério da Saúde, Brasília, DF, Brazil.

Programa Nacional de Hepatites Virais, Secretaria de Vigilância em Saúde, Ministério da Saúde, Brasília, DF, Brazil. 
Prevention strategies are crucial to control of infections and antimicrobial resistance (1). In 1992, the Brazilian government determined that all hospitals should implement a control program for health care-associated infections (2). In 2001, a government program created a network of high-complexity or teaching hospitals to monitor adverse events in the country.

The accuracy of information on health care-associated infections and susceptibility to antimicrobials is crucial for planning preventive strategies (3). The correct identification of agents of infections and antimicrobial susceptibility depends on the performance of the microbiology laboratory (4) and is necessary to provide good-quality health care in infectious diseases and all other fields of medicine $(5,6)$. Therefore, quality assurance in microbiology laboratories is crucial. While large, global studies such as SENTRY provide microbiological information about predominant pathogens and antimicrobial resistance patterns from a network of sentinel hospitals, the criteria used to include isolates may vary across study sites (7).

The objective of this study was to evaluate the results of a national prevalence survey on the quality and practices of microbiology laboratories in Brazil.

\section{MATERIALS AND METHODS}

The prevalence survey was carried out by the Department of Epidemiology at the School of Public Health of the University of São Paulo (Universidade de São Paulo, USP) and sponsored by the Pan American Health Organization (PAHO)/World Health Organization (WHO) and Brazil's National Health Surveillance Agency (Agência Nacional de Vigilância Sanitária, ANVISA). The evaluation of laboratory quality was the first step of a project to monitor and control microbial resistance in health care services.

The study sample included microbiology laboratories serving Brazilian hospitals that 1) had at least 10 intensive care beds and/or 2) were involved in the government health care adverse event reporting system. Hospitals with at least 10 intensive care beds and those participating in the adverse event report system were identified based on records from the Ministry of Health hospital system, and a data bank was organized. The laboratories were visited between April 2002 and December 2005, and their coordinators and routine microbiology staff were interviewed. Some laboratories served more than one hospital. The interviewers were professionals with knowledge of microbiology, trained by a microbiologist. During the visit, the interviewers made direct observations in addition to conducting the interviews. If there was any contradiction between an interview response and an observation, only the observation was considered. The interviewers asked the laboratory coordinators and routine microbiology staff questions about the laboratory and the sample hospital(s) it served. Topics included financing, infrastructure, human resources, equipment, procedures, quality control, and biosafety.

The Infection Control Department of Hospital das Clínicas, one of USP's three teaching hospitals, was commissioned by PAHO to analyze the data from databases created with EpiData 3.1 (EpiData Association, Odense, Denmark). The statistical analysis was carried out using Stata 7.0 (StataCorp, College Station, Texas, USA). After reviewing and cleaning the database, an initial descriptive analysis of the data was performed. The laboratories were classified by six levels of quality (0-5) (Table 1 ) based on criteria adapted from Brazilian national guidelines (8):

- Level 0: no minimal functioning conditions;

- Level 1: minimal functioning conditions but presented problems with the execution of basic routine;

- Level 2: minimal functioning conditions and adequate execution of basic routine but absence of adequate procedures for quality control;

- Level 3: minimal functioning conditions, adequate execution of basic routine, and adequate procedures for quality control, but no direct communication with infection control department;

- Level 4: minimal functioning conditions, adequate execution of basic routine, adequate procedures for quality control, and direct communication with infection control department, but no available advanced resources;

- Level 5: minimal functioning conditions, adequate execution of basic routine, adequate procedures for quality control, direct communication with the infection control department, and available advanced resources.

The defining criteria for "minimal functioning conditions" were: separate environment for sterilization; presence of a person on duty to receive samples 24 hours a day, 7 days a week; availability of binocular microscope, incubator, refrigerator, Bunsen burner, water bath, autoclave, mixer, scale, biological safety cabinet, blood agar, MacConkey agar, Mueller-Hinton agar, and chocolate agar; and use of a standardized requisition form. A laboratory was considered to have "minimal functioning conditions" if all criteria were met. The criteria for "adequate execution of basic routine" were: availability of potassium hydroxide preparation and blood agar for Streptococcus isolation; ability to carry out Gram and Ziehl-Neelsen staining, direct unstained examination, identification of non-fermenting bacteria and Enterococcus species, isolation of methicillin-resistant Staphylococcus

TABLE 1. Characteristics of the six levels of classification (0-5) used to rate the quality of microbiological services provided to hospitals in a national prevalence survey of $467^{\mathrm{a}}$ laboratories, Brazil, 2002-2005

\begin{tabular}{cccccc}
\hline & \multicolumn{5}{c}{ Characteristic } \\
\cline { 2 - 6 } & $\begin{array}{c}\text { Minimal } \\
\text { functioning } \\
\text { Classification }\end{array}$ & $\begin{array}{c}\text { Adequate } \\
\text { execution of } \\
\text { basic routine }\end{array}$ & $\begin{array}{c}\text { Adequate } \\
\text { procedures for } \\
\text { quality control }\end{array}$ & $\begin{array}{c}\text { Direct } \\
\text { communication } \\
\text { with infection } \\
\text { control department }\end{array}$ & $\begin{array}{c}\text { Availability of } \\
\text { advanced } \\
\text { resources }\end{array}$ \\
\hline Level 0 & No & No & & & \\
Level 1 & Yes & Yes & No & No & No \\
Level 2 & Yes & Yes & Yes & Yes & Yes \\
Level 3 & Yes & Yes & Yes & Yes &
\end{tabular}

a Only 431 of the 467 laboratories included in the study were rated for quality because 36 did not provide answers to all of the survey questions. 
aureus, and the test for extended spectrum beta-lactamase; use of standard methodologies such as those of the Clinical Laboratory Standards Institute (CLSI), specifically for antimicrobial susceptibility testing; and decontamination of biological waste. A laboratory was considered to provide "adequate execution of basic routine" if all criteria were met. The criteria for "adequate procedures for quality control" were: quality control with standard strains; approval from a reputable accrediting body (e.g., Brazil's National Accreditation Organization [ONU], or the International Organization for Standardization [ISO]); and written operational procedures. A laboratory was considered to provide "adequate procedures for quality control" if all criteria were met. The defining criteria for "availability of advanced resources" were: having an interfaced system with the hospital(s) for online results, an automated system for blood cultures, an automated system for identification and susceptibility testing, an automated system for mycobacteria, or an automated system for fungal identification; use of bacterial strain typing; ability to determine minimal inhibitory concentrations; ability to conduct susceptibility testing for non-standard drugs, or antifungals; and storage of important strains. A laboratory was considered to have "availability of advanced resources" if at least one of the criteria was met.

\section{RESULTS}

A total of 663 hospitals were identified as meeting the criteria for inclusion of their laboratory service providers (having at least 10 intensive care beds and/or being involved in the government health care adverse event reporting system) and 530 (79.9\%) were contactable. The laboratories that served these 530 hospitals were included in the study $(n=467)$. Coordinators and staff at all 467 microbiology laboratories were interviewed.

Most of the hospitals served by the 467 laboratories included in the study were private (393 or $74.2 \%$ ). A total of 79 (14.9\%) participated in the government adverse event reporting system. Only 47 $(8.9 \%)$ were teaching hospitals. About half $(50.2 \%)$ were located outside state capitals; $48.1 \%$ contracted the laboratories to provide third-party services; and $14.7 \%$ used the services of laboratories that served more than one hospital. Geographic distribution of the laboratories that were studied was as follows: 316 $(67.7 \%)$ were in the Southeast region; 87 $(18.6 \%)$ were in the South; $34(7.3 \%)$ were in the Northeast; and 15 (3.2\%) each were in the Central-West and North regions.

Only 431 of the 467 laboratories were classified by quality level because 36 laboratories did not provide answers for all of the survey questions. Most of the laboratories (368) were classified as Level 0 for quality (85.4\%), with only 29 $(6.7 \%)$ classified as Level 1, $25(5.8 \%)$ as Level 2, $4(0.9 \%)$ as Level 3, and none as Level 4 . Only $4(0.9 \%)$ of the laboratories studied were classified as Level 5 (minimal functioning conditions, adequate execution of basic routine, adequate procedures for quality control, direct communication with infection control, and available advanced resources).
The prevalence of minimal functioning conditions reported by the laboratory coordinators and staff can be seen in Table 2. All 467 laboratories had binocular microscopes, but for all other characteristics prevalence was below $100 \%$. Twenty-one laboratories did not have a Bunsen burner, 271 laboratories did not have biological safety cabinets, 80 did not have standardized requisition forms, and 3 did not have blood agar medium.

None of the characteristics used to evaluate the execution of basic routine was executed by $100 \%$ of the laboratories. One laboratory did not perform gram staining and 12 did not perform Ziehl-Neelsen staining; 196 did not test for extended spectrum beta-lactamase; 191 could not identify Enterococcus species; and 266 did not perform quality control with standard strains (Table 2).

TABLE 2. Number of laboratories demonstrating selected characteristics in national prevalence survey to assess quality of microbiological services provided to hospitals, Brazil, 2002-2005

\begin{tabular}{|c|c|c|}
\hline Characteristic $(n)^{\mathrm{a}}$ & No. & $\%$ \\
\hline \multicolumn{3}{|l|}{ "Minimal functioning conditions" } \\
\hline Separate environment for sterilization (467) & 401 & 85.9 \\
\hline Person on duty able to provide sample conservation (443) & 292 & 65.9 \\
\hline Binocular microscope (467) & 467 & 100 \\
\hline Incubator $\left(35^{\circ} \mathrm{C}\right)(467)$ & 466 & 99.8 \\
\hline Refrigerator (467) & 464 & 99.4 \\
\hline Bunsen burner (467) & 446 & 95.5 \\
\hline Water bath (467) & 441 & 94.4 \\
\hline Autoclave (467) & 460 & 98.5 \\
\hline Mixer (467) & 292 & 62.5 \\
\hline Scale (467) & 413 & 88.4 \\
\hline Biological safety cabinet (467) & 196 & 41.9 \\
\hline Blood agar (467) & 464 & 99.4 \\
\hline MacConkey agar (467) & 456 & 97.6 \\
\hline Chocolate agar (467) & 445 & 95.3 \\
\hline Mueller-Hinton agar (467) & 451 & 96.6 \\
\hline Standardized requisition form (461) & 381 & 82.6 \\
\hline \multicolumn{3}{|l|}{ "Adequate execution of basic routine" } \\
\hline Gram staining (467) & 466 & 99.8 \\
\hline Ziehl-Neelsen staining (467) & 455 & 97.4 \\
\hline Direct unstained examination (467) & 433 & 92.7 \\
\hline Potassium hydroxide $(\mathrm{KOH})$ preparation $(467)$ & 368 & 78.8 \\
\hline Identification of nonfermenting bacteria (467) & 428 & 91.6 \\
\hline Use of blood agar for Streptococcus isolation (467) & 463 & 99.1 \\
\hline Identification of Enterococcus species (467) & 276 & 59.1 \\
\hline $\begin{array}{l}\text { Isolation and identification of methicillin-resistant } \\
\text { Staphylococcus aureus (464) }\end{array}$ & 380 & 82.0 \\
\hline Use of test for extended spectrum beta-lactamase (466) & 270 & 57.9 \\
\hline $\mathrm{CLSI}^{\mathrm{b}}$ as standard methodology (467) & 337 & 72.2 \\
\hline Decontamination of biological waste (463) & 413 & 89.2 \\
\hline \multicolumn{3}{|l|}{ "Adequate procedures for quality control" } \\
\hline Quality control with standard strains (467) & 201 & 43.0 \\
\hline Approval by reputable accrediting body (466) & 79 & 17.0 \\
\hline Written operational procedures (467) & 73 & 16.6 \\
\hline
\end{tabular}

${ }^{a}$ Number of laboratories that provided answers to the corresponding survey questions.

b CLSI: Clinical Laboratory Standards Institute. 
The advanced resource most frequently reported by the laboratories studied was having an automated system for blood cultures. More than 30\% of the laboratories reported 1) having an automated system for identification and susceptibility testing; 2) having the ability to determine minimal inhibitory concentration; 3) performing susceptibility testing for nonstandard drugs; and 4) storing important strains (Table 3).

Biological safety cabinets are crucial for safe handling of infectious organism (even when automated systems are used) because specimens require storage while processing. A high proportion of laboratories surveyed did not have biological safety cabinets even though they had advanced resources or equipment. More than $30 \%$ of laboratories without safety cabinets had automated systems for blood cultures or for identification and susceptibility testing, and provided determination of minimal inhibitory concentration or susceptibility testing for nonstandard drugs.

In a bivariate analysis, the following characteristics were associated with the lowest quality of microbiology services: serving hospitals that did not belong to the government adverse event reporting system; serving private hospitals; serving nonteaching hospitals; and serving hospitals located outside state capitals. The following variables were not associated with quality: geographic region; providing third-party services; and serving more than one hospital (Table 4).

\section{DISCUSSION}

The results of this study indicate multiple problems in terms of the quality and practices of microbiology laboratories in Brazil. Most microbiology laboratories studied did not have minimal functioning conditions. One laboratory reported not being able to perform gram staining. In a European consensus report, access to laboratory support for infection control was deemed one of the 10 most important aspects for the prevention and control of health care-associated infection (4), a crucial component for improving overall patient care. Surveillance culturing to identify patients carrying multiresistant organisms, another variable that is largely dependent on laboratories, is considered an important measure for controlling resistance within hospitals (9). The current findings can be used to pinpoint problematic areas in laboratory services in Brazil in order to improve patient outcomes.

Ziehl-Neelsen staining was not performed by $2.6 \%$ of the laboratories studied. This type of staining is a simple, lowcost method for diagnosing tuberculosis (TB). In Brazil, TB is highly prevalent, with an annual incidence of 38 cases per 100000 inhabitants (10). Early diagnosis and treatment is crucial for countrywide control of this disease, and direct staining of sputum is the primary diagnostic method. It is quite surprising and worrisome that despite Brazil's national TB program many hospitals equipped with intensive care units cannot provide this

TABLE 3. Number of laboratories demonstrating use of advanced equipment and resources in national prevalence survey to assess quality of microbiological services provided to hospitals, Brazil, 2002-2005

\begin{tabular}{lrr}
\hline \multicolumn{1}{c}{ Characteristic $(n)^{\text {a }}$} & No. & $\%$ \\
\hline Pre-analytic phase & 110 & 23.6 \\
$\quad$ Information system interfaced with hospital for online results (466) & & \\
Equipment & 202 & 43.3 \\
$\quad$ Automated system for blood culture (467) & 177 & 37.9 \\
$\quad$ Automated system for identification and susceptibility testing (467) & 37 & 7.9 \\
$\quad$ Automated system for mycobacteria (466) & 83 & 21.1 \\
$\quad$ Automated system for fungal identification (394) & 52 & 11.1 \\
Procedures & 184 & 39.4 \\
$\quad$ Bacterial typing (467) & 195 & 41.9 \\
$\quad$ Minimal inhibitory concentration determination (467) & 41 & 8.8 \\
Susceptibility testing for nonstandard drugs (465) & & \\
$\quad$ Antifungal susceptibility testing (466) & 139 & 30.3 \\
Post-analytic phase & &
\end{tabular}

\footnotetext{
a Number of laboratories that provided answers to the corresponding survey questions.
}

test. In addition, $58.1 \%$ of the laboratories reported not having biological safety cabinets, and more than $30 \%$ of those without safety cabinets reported using advanced equipment. These findings suggest significant disparity in the distribution of the country's limited resources, which may be attributable to socioeconomic differences within populations in each region (11). To meet the goal of universal access to good-quality health care, a revised, better-informed definition of priorities for laboratory resource distribution seems advisable.

In the current study, serving hospitals participating in the government adverse event reporting system was associated with a higher level of quality of laboratory services. Those hospitals receive financing and extensive training, so it was not surprising that the laboratories they used seemed to have better-qualified human resources. The association between the lowest-quality laboratory services and location outside state capitals may be explained by difficulties in accessing information in smaller communities. One interesting finding was that geographic region was not associated with level of quality; poor regions such as the Northeast and North did not differ significantly from rich regions (e.g., the Southeast) in terms of the quality and practices of their laboratory services. Another finding of note was the presence of better-qualified professionals at laboratories serving teaching hospitals, possibly due to laboratory staff involvement in teaching activities.

The influence of companies that produce equipment and products for laboratories may be one of the forces driving the use of more sophisticated resources such as automated systems, even in laboratories where basic techniques and routines are lacking. This may reflect the effect of economic pressures on uninformed professionals. These types of idiosyncrasies occur in many fields in developing countries where limited resources are distributed inefficiently (12).

Based on the interim analysis of the results of this survey, measures to improve the quality of laboratories have already been initiated. In 2005, ANVISA officially adopted CLSI standards for antimicrobial susceptibility testing, and provided online access to a Portuguese translation of the original CLSI document, and control strains, to all laboratories. In addition, from 2005 to 2007, extensive training in microbiology ser- 
TABLE 4. Characteristics of 368 laboratories that received the lowest quality rating (Level 0 ) in a national prevalence survey assessing microbiological services provided to hospitals $\left(n=431^{\mathrm{a}}\right)$, Brazil, 2002-2005

\begin{tabular}{|c|c|c|c|c|c|}
\hline Characteristic & $\begin{array}{l}\text { Level } 0^{b} \\
(n=368)\end{array}$ & $\begin{array}{l}\text { Level } \geq 1 \\
(n=63)\end{array}$ & $\mathrm{OR}^{\mathrm{c}}$ & $95 \% \mathrm{Cl}^{\mathrm{d}}$ & $p^{\mathrm{e}}$ \\
\hline \multicolumn{6}{|l|}{$\begin{array}{l}\text { Serving hospitals that do not belong to the } \\
\text { government adverse event reporting system }\end{array}$} \\
\hline & $321(87.2 \%)$ & $42(66.7 \%)$ & 3.41 & $1.78-6.53$ & $<0.001$ \\
\hline Serving private hospitals & $283(76.9 \%)$ & $40(63.5 \%)$ & 1.91 & $1.04-3.50$ & 0.02 \\
\hline Serving nonteaching hospitals & $341(92.7 \%)$ & $49(77.8 \%)$ & 3.61 & $1.67-7.75$ & $<0.001$ \\
\hline Serving hospitals located outside state capitals & $208(56.5 \%)$ & $23(36.5 \%)$ & 2.20 & $1.26-4.08$ & 0.003 \\
\hline Geographic region & & & - & - & 0.18 \\
\hline South & 74 & 6 & & & \\
\hline Southeast & 244 & 49 & & & \\
\hline Central-West & 14 & 1 & & & \\
\hline Northeast & 25 & 4 & & & \\
\hline North & 11 & 3 & & & \\
\hline $\begin{array}{l}\text { Contracted by hospitals to provide third-party } \\
\text { services }\end{array}$ & $170(46.2 \%)$ & 27 (42.9\%) & 1.14 & $0.65-2.03$ & 0.62 \\
\hline Serving more than one hospital & $32(8.7 \%)$ & $4(6.3 \%)$ & 1.40 & $0.45-4.67$ & 0.53 \\
\hline
\end{tabular}

a $A$ total of 467 laboratories were included in the study sample but only 431 were rated for quality because 36 did not provide answers to all of the survey questions.

b Level 0: absence of "minimal functioning conditions" (separate environment for sterilization; presence of a person on duty to receive samples 24 hours a day, 7 days a week; availability of binocular microscope, incubator, refrigerator, Bunsen burner, water bath, autoclave, mixer, scale, biological safety cabinet, blood agar, MacConkey agar, Mueller-Hinton agar, and chocolate agar; and use of a standardized requisition form).

c OR: odds ratio.

d $\mathrm{Cl}$ : confidence interval.

e Based on chi square test.

vices was provided to reference laboratories in each state capital as well as large hospitals. However, an improved knowledge base is not always reflected in subsequent policymaking; there is often a gap between medical theories and actual practice (13). Overcoming this gap is another large challenge.
The main limitations of this study stem from the process used in the evaluation. Most data were obtained by interviewing the coordinators and microbiology staff at the laboratories. Although the interviewers were specially trained to observe various aspects of laboratory practices, the accuracy of the information they obtained can not be guaranteed.

In conclusion, most Brazilian microbiology laboratories serving hospitals with intensive care units did not provide minimal functioning conditions. Factors associated with higher quality were: serving teaching or public hospitals; serving hospitals involved in the government adverse event reporting system; and serving hospitals located in a state capital. Although the current data are only drawn from one region, the authors believe they most likely reflect the status of laboratory services and practices in other regions, especially in developing countries.

Acknowledgments. This study was funded by Brazil's National Health Surveillance Agency (ANVISA) and the Pan American Health Organization (PAHO) (cooperation agreement No. 37).

\section{Conflict of interest. None}

\section{REFERENCES}

1. Lowy FD. Antimicrobial resistance: the example of Staphylococcus aureus. J Clin Invest. 2003;111(9):1265-73.

2. Ministério da Saúde (BR). Portaria no. 930, 27 de agosto de 1992. Expede, na forma dos anexos, normas para o controle das infecções hospitalares. Diário Oficial da União, Brasília, 04 set. 1992.

3. Peterson LR, Hamilton JD, Baron EJ, Tompkins LS, Miller JM, Wilfert CM, et al. Role of clinical microbiology laboratories in the management and control of infectious diseases and the delivery of health care. Clin Infect Dis. 2001;32(4):605-11.

4. Cookson B, Mackenzie D, Coutinho AP, Russell I, Fabry J. Consensus standards and performance indicators for prevention and control of healthcare-associated infection in Europe. J Hosp Infect. 2011;79(3):260-4.

5. Lipsky BA, Peters EJ, Senneville E, Berendt AR, Embil JM, Lavery LA, et al. Expert opinion on the management of infections in the diabetic foot. Diabetes Metab Res Rev. 2012;28 Suppl 1:163-78.
6. Coghe F, Orrù G, Pautasso M, Ferraguti P, Sanna P, Fanos V. The role of the laboratory in choosing antibiotics. J Matern Fetal Neonatal Med. 2011;24 Suppl 2:18-20.

7. Pfaller MA, Jones RN, Doern GV, Sader HS, Hollis RJ, Messer SA. International surveillance of bloodstream infections due to Candida species: frequency of occurrence and antifungal susceptibilities of isolates collected in 1997 in the United States, Canada, and South America for the SENTRY Program. The SENTRY Participant Group. J Clin Microbiol. 1998;36(7):1886-9.

8. Agência Nacional de Vigilância Sanitária, Ministério da Saúde (BR). Manual de Microbiologia Clínica para o Controle de Infecção em Serviços de Saúde. Brasília: MS; 2004. Available from: http://www.anvisa.gov.br/ servicosaude/manuais / microbiologia.asp Accessed 26 January 2012.

9. Cohen MJ, Block C, Levin PD, Schwartz C, Gross I, Weiss Y, et al. Institutional control measures to curtail the epidemic spread of carbapenem-resistant Klebsiella pneumoniae: a 4-year perspective. Infect Control Hosp Epidemiol. 2011;32(7):673-8.

10. Ministério da Saúde (BR). Informe eletrônico da tuberculose. Bol Eletrônico Epidemiol. 2009;2:1-4.

11. Neri M, Soares W. Desigualdade social e saúde no Brasil. Cad Saude Publica. 2002;18(Suppl):77-87.

12. Makinen $M$, Waters $H$, Rauch $M$, Almagambetova N, Bitran R, Gilson L, et al. Inequalities in health care use and expenditures: empirical data from eight developing countries and countries in transition. Bull World Health Organ. 2000;78(1):55-65.

13. Das J. The quality of medical care in lowincome countries: from providers to markets. PLoS Med. 2011;8(4):e1000432.

Manuscript received on 3 February 2012. Revised version accepted for publication on 29 November 2012. 
RESUMEN Este artículo describe una encuesta realizada en Brasil en laboratorios de microbiología $(n=467)$ que prestaban servicio a hospitales que contaban al menos con 10 camas de cuidados intensivos. Se entrevistó a los coordinadores y los laboratorios

Encuesta de prevalencia nacional para evaluar la calidad de los laboratorios de microbiología en el Brasil: importancia de la definición de prioridades para asignar recursos limitados

Palabras clave se clasificaron de la siguiente manera: nivel 0 (sin condiciones de funcionamiento mínimas: 85,4\% de los laboratorios), nivel 1 (condiciones de funcionamiento mínimas pero ejecución inadecuada del trabajo habitual básico: 6,7\%), nivel 2 (condiciones de funcionamiento mínimas y ejecución adecuada del trabajo habitual básico, pero sin procedimientos de control de calidad apropiados: 5,8\%), nivel 3 (condiciones de funcionamiento mínimas, ejecución adecuada del trabajo habitual básico y procedimientos de control de calidad apropiados, pero sin comunicación directa con el departamento de control de infecciones: $0,9 \%$ ), nivel 4 (condiciones de funcionamiento mínimas, ejecución adecuada del trabajo habitual básico, procedimientos de control de calidad apropiados y comunicación directa con el departamento de control de infecciones, pero sin recursos avanzados disponibles: ningún laboratorio) y nivel 5 (condiciones de funcionamiento mínimas, ejecución adecuada del trabajo habitual básico, procedimientos de control de calidad apropiados, comunicación directa con el departamento de control de infecciones y recursos avanzados disponibles: 0,9\%). Doce laboratorios no realizaban la tinción de Ziehl-Neelsen, 271 no contaban con cámaras de seguridad biológica, y más de 30\% de los laboratorios que carecían de cámaras de seguridad biológica tenían sistemas automatizados. La escasa calidad se asoció a la falta de participación en el programa gubernamental de notificación de acontecimientos adversos, a los hospitales privados, a los hospitales no docentes y a la ubicación de los hospitales fuera de las capitales de los estados. Los resultados pueden reflejar lo que ocurre en muchos otros países con recursos limitados, donde es importante definir las prioridades.

Laboratorios de hospital; encuestas de la atención de la salud; garantía de la calidad de atención de salud; téchnicas microbiológicas; indicadores de calidad de la atención de la salud; Brasil. 